\title{
Palaeogeographical patterns in Late Ordovician bryozoan morphology as proxies for temperature
}

\author{
ANDREA JIMÉNEZ-SÁNCHEZ, PAUL D. TAYLOR \& JAVIER B. GÓMEZ
}

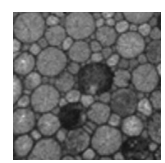

\begin{abstract}
Several studies have revealed temperature-related patterns in recent bryozoans, both in the chemical composition of the skeleton and in the morphological characters of the colonies, but comparable studies on Palaeozoic bryozoans are lacking. In this paper a statistical analysis of the morphological differences is undertaken between congeneric species of some Ordovician bryozoans from warm- and cold-water settings. For this study ten eurythermic cosmopolitan bryozoan genera from the Upper Ordovician were selected from the Mediterranean, Avalonia, Baltic and Laurentia-Siberian provinces. These genera are: Ceramopora and Ceramoporella (Cystoporata); Diplotrypa, Eridotrypa, Hallopora, Heterotrypa, Monticulipora and Trematopora (Trepostomata); Graptodictya (Cryptostomata); and Kukersella (Cyclostomata). The study involved 154 samples belonging to 104 different species. Twenty-eight morphological characters were measured, although only 21 were used in the final statistical analysis. Univariate (t, F, Kolmogorov-Smirnov and Mann-Whitney tests), multivariate discriminant and multivariate ordination (Principal Coordinates, Principal Components, Correspondence, and Detrended Correspondence) analyses were performed on the data. For the univariate and multivariate discriminant analyses, the total set of samples was divided a priori into cold- and warm-water subsets based on palaeolatitude: samples from the Mediterranean province were attributed to the cold-water subset, whereas samples from Avalonia, Baltic and the Laurentian-Siberian provinces were included in the warm-water subset. For the multivariate ordination analysis no a priori grouping by water temperature was imposed, and the aim of these analyses was to test whether different samples were correctly arranged along a water temperature gradient. The univariate statistical analysis showed that there are clear morphological differences between cold- and warm-water species in six of the ten Late Ordovician bryozoan genera analysed in this study, although these differences are only evident for some of the characters used, and only when the analysis is performed on individual genera. The best characters to differentiate species by water temperature are those related to the size of the zooidal polymorphs, especially the diameters of the autozooecia, mesozooecia and exilazooecia. With the exception of one genus (Trematopora), cold-water species have larger zooids. The discriminant analysis was able to classify correctly as warm- or cold-water $100 \%$ of the samples for two genera, slightly below $95 \%$ for two other genera, and between $67 \%$ and $90 \%$ for the remaining six genera. Finally, the multivariate ordination analysis was able to separate species by palaeogeographical province in some genera, but these provinces were not correctly arranged along a palaeolatitudinal gradient using any of the methods used. - Key words: bryozoans, cosmopolitan genera, latitudinal adaptations, univariate and multivariate statistical analysis.
\end{abstract}

JIMÉNEZ-SÁNCHEZ, A., TAYLOR, P.D. \& GÓMEZ, J.B. 2013. Palaeogeographical patterns in Late Ordovician bryozoan morphology as proxies for temperature. Bulletin of Geosciences 88(2), 417-426 (10 figures, 2 tables, online supplementary material). Czech Geological Survey, Prague. ISSN 1214-1119. Manuscript received November 20, 2012; accepted in revised form February 21, 2013; published online May 31, 2013; issued June 7, 2013.

Andrea Jiménez-Sánchez, (corresponding author), Center of Biology, Geosciences and Environmental Education, University of West Bohemia, Klatovská 51, 30619 Plzen̆, Czech Republic; jimenez@cbg.zcu.cz・Paul D. Taylor, Department of Earth Sciences, Natural History Museum, Cromwell Road, London, SW7 5BD, UK; p.taylor@nhm.ac.uk • Javier B. Gómez, C/ Pedro Cerbuna 12, 50009 Zaragoza, Spain; jgomez@unizar.es

The Bryozoa is a phylum of mostly marine invertebrates containing species that are adapted to living in waters of a wide range of temperatures, from the warmth of the tropics to the cold of the Arctic and Antarctic oceans. However, their temperature-related distribution has changed since the Palaeozoic, when they were most abundant on tropical platforms, compared with today, where their abundance is greater in higher latitudes (Taylor \& Allison 1998, Taylor $\&$ Sendino 2010). Notwithstanding the prevalence of bryo- zoans on tropical platforms in the Palaeozoic, during the Late Ordovician (455-445 Ma), they were one of the most abundant invertebrate groups, together with brachiopods and echinoderms, on the North Gondwana platforms, located during this time at high latitudes, between $40^{\circ}$ and $60^{\circ}$ S (Jiménez-Sánchez \& Villas 2010).

During the Late Ordovician a total of 68 bryozoan genera are known to have colonised the cold carbonate platforms of the Mediterranean province (Cocks \& Torsvik 
2006, Jiménez-Sánchez \& Villas 2010); 22 of these genera were endemic to this province while 46 were also present on tropical and equatorial carbonate platforms (JiménezSánchez \& Villas 2010). Study of the cosmopolitan genera offers the possibility of ascertaining if and how these genera were able to adapt morphologically, chemically and mineralogically to life across such a wide range of temperatures.

Published studies carried out on Recent bryozoans belonging to the orders Cheilostomata and Cyclostomata point to some common temperature-related patterns. Carbonate skeletons of cheilostome bryozoans living in warm waters comprise calcite, aragonite or are bimineralic (with calcite overlain by aragonite), and in those employing calcite the percentage of $\mathrm{Mg}$ is often high (Smith et al. 2006, Taylor et al. 2009). On the other hand, in cold-water, cheilostome species with aragonitic and bimineralic skeletons are rare and the $\mathrm{Mg}$ content in the calcite is typically lower (Kuklinski \& Taylor 2008, 2009; Loxton et al. 2012). These mineralogical and chemical differences in bryozoan skeletons have been linked to environmental factors - mainly temperature - because they have also been found to occur within congeneric species that inhabit different temperature habitats. In addition, Schäfer \& Bader (2008) showed that the Mg content of bryozoan calcite could vary in a single skeleton depending on the season when the calcite was secreted, its content being lower in cold than warm water. We here place the limit between cold- and warm-water at around $18{ }^{\circ} \mathrm{C}$, the temperature beneath which tropical corals cannot live at the present-day (e.g., Schlager 2005, fig. 2.8).

In addition to these mineralogical and chemical variations, cold- and warm-water species may show differences in morphology, including the development of polymorphic zooids and other features linked to environmental variations in seasonality, predator pressure, availability of food etc. For example, according to Hughes \& Jackson (1990) and Kuklinski \& Taylor (2008), avicularia, generally regarded as having a defensive role, are smaller and fewer in number in high latitude congeneric species, suggesting that predator pressure is relatively less important than physical stresses in these environments. In addition, there is an inverse intraspecific relationship between the size of the zooids in living cheilostome bryozoan colonies and the ambient temperature at the time of budding (see Okamura et al. 2011). Limited evidence suggests that this relationship is also true between congeneric species: Kuklinski \& Taylor (2008) found that the size of the autozooecia in cheilostome species belonging to six of the eight genera they studied was significantly greater in the Arctic than in congeneric species from lower latitude, warmer water sites.

The aim of this paper is to test statistically for morphological differences in representative Upper Ordovician eurythermic bryozoan genera that inhabited the equatorial and tropical latitudes of Avalonia and Baltic and Laurentia-
Siberia provinces, compared with bryozoans from the almost polar latitudes of the Mediterranean province (Carnic Alps, Montagne Noire, Iberian Chains and Libya). As we are considering palaeolatitude as a proxy for water temperature, the prediction is that related (e.g. congeneric) species from different palaeolatitudinal settings will show consistent morphological differences, similar to those found among Recent bryozoans from waters of different temperature.

\section{Studied material}

In this study the term 'sample' is used for species from a single locality. Thus, if the same species has been described in four different localities, it is counted here as four different 'samples' of the same species. A sample can be a single colony, or several colonies or fragments of colonies, provided they come from the same locality and have been identified as conspecific.

A total of ten genera were studied, all present at both high and low palaeolatitudes. These genera are: Ceramopora (Cystoporata; 9 samples belonging to 6 species), Ceramoporella (Cystoporata; 15 samples, 9 species), Diplotrypa (Trepostomata; 17 samples, 14 species), Eridotrypa (Trepostomata; 22 samples, 14 species), Graptodictya (Cryptostomata; 9 samples, 6 species), Hallopora (Trepostomata; 32 samples, 23 species), Heterotrypa (Trepostomata; 5 samples, 3 species), Kukersella (Cyclostomata; 12 samples, 1 species), Monticulipora (Trepostomata; 21 samples, 17 species) and Trematopora (Trepostomata; 12 samples, 11 species). One-hundred and seven of these samples came from the low and middle-low latitude provinces of Avalonia, Baltic and Laurentia-Siberia, and the rest (45 samples) from the high and middle-high latitude of Mediterranean province. We have also included a small number of samples belonging to the genera Diplotrypa, Eridotrypa, Graptodictya and Monticulipora from the late Middle Ordovician in order to enlarge the sample size for each genus in all studied regions. The species Hallopora elegantula, Kukersella borealis and Monticulipora kolaluensis have been recorded from low and middle-low latitudes as well as high- and middle-high latitudes.

Most of the material used is stored in the Natural History Museum, London (NHMUK) and in the Paleontological Museum of the University of Zaragoza (MPUZ), Spain. The rest of the samples are stored in other European and American institutions. A list of samples, localities and institutions where the samples are stored is provided as online supplementary material (www.geology.cz).

\section{Methodology}

Morphological study of the bryozoan genera listed above was undertaken by measuring several characteristics of the 
Table 1. Morphological characters used in the statistical analysis.

\begin{tabular}{|c|c|c|c|c|c|c|c|c|c|c|c|c|}
\hline Character & Transcription & 㞯 & $\begin{array}{l}\vdots \\
\vdots \\
\vdots \\
\vdots \\
\vdots \\
\vdots \\
\vdots\end{array}$ & 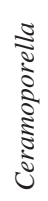 & 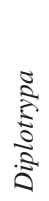 & 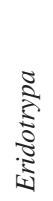 & 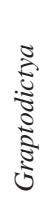 & $\begin{array}{l}\frac{0}{0} \\
\frac{0}{0} \\
\frac{0}{2}\end{array}$ & 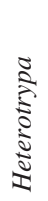 & 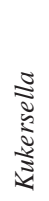 & 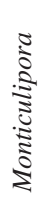 & 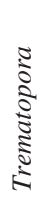 \\
\hline AAZS & Autozooecial intersection angle with colony surface & & & & & & & $\mathrm{X}$ & $\mathrm{X}$ & & & \\
\hline $\mathrm{AD}$ & Autozooecial diameter & & $\mathrm{X}$ & $\mathrm{X}$ & $\mathrm{X}$ & $\mathrm{X}$ & & $\mathrm{X}$ & $\mathrm{X}$ & $\mathrm{X}$ & $\mathrm{X}$ & $\mathrm{X}$ \\
\hline ADalWTh & Autozooecial distal wall thickness & & & & & & & & & $\mathrm{X}$ & & \\
\hline $\mathrm{AD}_{\text {large }}$ & Autozooecial large diameter & & & & & & $\mathrm{X}$ & & & & & \\
\hline AltPxWTh & Autozooecial lateral and proximal wall thickness & & & & & & & & & $\mathrm{X}$ & & \\
\hline AthD & Acanthostyle diameter & & & & & & & & $\mathrm{X}$ & & & $\mathrm{X}$ \\
\hline AWThEx & Autozooecial wall thickness in exozone & & $\mathrm{X}$ & $\mathrm{X}$ & & $\mathrm{X}$ & & $\mathrm{X}$ & $\mathrm{X}$ & & & $\mathrm{X}$ \\
\hline BchD & Branch diameter & & & & & & & $\mathrm{X}$ & $\mathrm{X}$ & $X$ & & $\mathrm{X}$ \\
\hline $\mathrm{BchD}_{\text {small }}$ & Branch small diameter & & & & & & $\mathrm{X}$ & & & & & \\
\hline EndozoneD & Endozone diameter & & & & & & & & $\mathrm{X}$ & $\mathrm{X}$ & & \\
\hline EndozoneTh & Endozone thickness & & & & & & $\mathrm{X}$ & & & & & \\
\hline ExiD & Exilazooecial diameter & & $X$ & $\mathrm{X}$ & & & & & & & & \\
\hline ExozoneTh & Exozone thickness & & & & & & & & $\mathrm{X}$ & $\mathrm{X}$ & & \\
\hline MD & Mesozooecial diameter & & & & $\mathrm{X}$ & & & $\mathrm{X}$ & $\mathrm{X}$ & & $\mathrm{X}$ & $\mathrm{X}$ \\
\hline $\mathrm{N}^{\circ} \mathrm{A} 1 \mathrm{~mm}$ & Number of autozooecia per one millimetre & & & & $\mathrm{X}$ & & & & $\mathrm{X}$ & & $\mathrm{X}$ & $\mathrm{X}$ \\
\hline $\mathrm{N}^{\circ} \mathrm{A} 1 \mathrm{~mm}^{2}$ & Number of autozooecia per one square millimetre & & & & & & & $\mathrm{X}$ & $X$ & & $X$ & $\mathrm{X}$ \\
\hline $\mathrm{N}^{\circ}$ Ath $1 \mathrm{~mm}^{2}$ & Number of acanthostyle per one square millimetre & & & & & & & & & & & $\mathrm{X}$ \\
\hline $\mathrm{N}^{\circ} \mathrm{M} 1 \mathrm{~mm}$ & Number of mesozooecia per one millimetre & & & & & & & & & & $\mathrm{X}$ & \\
\hline $\mathrm{N}^{\circ} \mathrm{M} 1 \mathrm{~mm}^{2}$ & Number of mesozooecia per one square millimetre & & & & & & & & & & $\mathrm{X}$ & \\
\hline $\mathrm{N}^{\circ} \mathrm{MDph} 1 \mathrm{~mm}$ & Number of mesozooecial diaphragms per one millimetre & & & & & & & $\mathrm{X}$ & & & & \\
\hline ZWTh & Zooecial wall thickness & & & & $\mathrm{X}$ & & & & & & $\mathrm{X}$ & \\
\hline
\end{tabular}

colonies and of component parts such as individual polymorph zooids and acanthostyles (Fig. 1). The resulting quantitative data was analysed with univariate and multivariate statistical techniques using the PAST v. 2.15 palaeontological software (Hammer et al. 2008).

A total of 28 different morphological characters were measured, both from the colony (height and diameter of branches in most cases) and from individual elements of the colony (autozooecia, mesozooecia, exilazooecia, acanthostyles etc.). Measurements were taken either directly from thin sections of the samples using a microscope graticule, or from scaled photographs. Not all of the measurable morphological characters could be taken from each sample due to the lack of correctly oriented thin sections. Only those characters that were measured in at least $80 \%$ of the samples of particular genera were included in the final statistical analysis. Missing values in the remaining characters for a genus were computed as the arithmetic mean of the character in the samples belonging to the same temperature range (i.e. cold- or warm-water). Table 1 lists the characters used in the statistical analyses (21 out of the initial 28), together with the genera in which the characters were measured.

In order to check whether a specific character could be used to separate cold- and warm-water taxa, several uni- variate and multivariate statistical tests were performed.

First, using the a priori knowledge of the palaeogeographical positions of each palaeocontinent in the Late Ordovician (Fortey \& Cocks 2003, Jiménez-Sánchez \& Villas 2010), the total sample was divided into two subsamples: a cold-water subsample (Mediterranean province) and a warm-water subsample (Avalonia region and Baltic and Laurentia-Siberian provinces). It is important to remember here that all of the genera selected for this study contain both cold- and warm-water species.

The first statistical test checked whether the two subsamples (for a specific genus) belonged to the same underlying population or to two different populations. Differences in mean, variance and distribution were tested.

The type of test performed depended on the probability distribution of the sub-samples for each genus. If both sub-samples of a genus were Shapiro-Wilk normally distributed, then the ' $\mathrm{t}$ ' test of equality of means and the ' $F$ ' test of equality of variances were performed. On the other hand, if either of the two sub-samples of the genus was not Shapiro-Wilk normally distributed, then two non-parametric tests were performed: the Mann-Whitney test for the equality of means, and the Kolmogorov-Smirnov test for the equality of distributions. Normality was tested for a level of significance of 5\% (i.e., the null hypothesis of an 
underlying normal distribution was rejected if the p-value is smaller than 0.05).

The outcome of the previous univariate analysis determines whether a specific character could be used to split, in a statistically significant sense, cold- from warm-water species belonging to the same genus. But this statistical significance can be marginal, in which case the differences cannot be used reliably to classify species of the same genus as either cold- or warm-water. In order to assess the reliability of the assignation of a new taxon to one of the two subsamples (cold- or warm-water), a multivariate discriminant analysis was performed. Discriminant analysis is a statistical technique allowing the study of differences between two or more groups of objects with respect to several variables simultaneously. In this sense it can be understood as a sort of multivariate version of the univariate analysis explained above. The aim of the method is to find a function (the discriminant function) that best separates one group from the other. Once the discriminant function is known, any new species from the studied genera can be assigned to one or the other of the two groups. A discriminant function able to classify at least $95 \%$ of the species in the correct (a priori) group is considered here to be good.

In the previous statistical analyses taxa were separated on the basis of their palaeogeographical occurrence into two water temperature regimes: cold- and warm-water. However, water temperature is not a cold/warm binary variable. There are obvious temperature gradients from the cold waters of the near-polar location of some parts of the Mediterranean province, to the warm waters of the equatorial regions of Laurentia. Consequently, in order to check for environmental temperature gradients and their impact on morphological features, several ordination and data clustering multivariate analyses were carried out, comprising Principal Coordinates, Principal Components, Correspondence, Detrended Correspondence, and Discriminant analyses. The Euclidean distance was used in all multivariate tests requiring a similarity measure.

\section{Results}

\section{Univariate analysis}

Table 2 shows the results of the univariate tests performed. The first column gives the genus and the analysed character. The second column states the number of studied samples per genus, divided into subsets from cold- and warm-water. In the third column the results of the normality tests for both populations, expressed in terms of p-values, are given. A significance level of 5\% was chosen, so p-values less than 0.05 indicate that the sample did not pass this test, i.e., the distribution of the subjacent population is not normal; in this column numbers in boldface indi- cate that both subsamples (cold- and warm-water) passed the normality test, whereas numbers in red indicate that at least one subsample did not pass this test for a specific character. In the fourth and fifth columns, respectively, are given the results of the ' $F$ ' and ' $t$ ' tests; these results are only shown when both subsamples passed the normality test (crossed-out figures mean that the normality test was not passed). The sixth and seventh columns show the results of the Kolmogorov-Sminov (K-S) and MannWhitney (M-N) tests, respectively; these tests were used only when subsamples did not pass the normality test. The last column gives the arithmetic mean of each analysed character in the cold- and warm-water subsamples; the higher value is marked in boldface.

The results summarized in Table 2 show that not all characters were able to discriminate between cold- and warm-water subsamples, some characters being much more useful than others. The best characters to differentiate the subsamples are autozooecial diameter (AD) and the diameters of the different polymorphic mesozooecia and exilazooecia (MD and ExiD, respectively). In all genera these diameters are larger in cold-water species than they are in warm-water species (Fig. 2), with the exception of the genus Trematopora in which the diameters of autozooecia and mesozooecia are smaller in species from cold- than warm-water, although it is still possible to differentiate the subsamples using the Mann-Whitney test for the equality of means.

None of the characters analysed in the genera Ceramopora, Graptodictya, Heterotrypa and Kukersella were able to separate the cold- from warm-water subsamples. Genera belonging to the order Trepostomata seem to show the greatest morphological differences between cold- and warm-water species; however, as pointed out above, there are exceptions (e.g., Heterotrypa). The genus Ceramoporella (order Cystoporata) is also notable because the two subsamples are clearly distinguishable using two of the three analysed characters (AD and ExiD).

The character 'autozooecial diameter (AD)' is the only one common to all ten studied genera. This fact allowed an additional univariate analysis to test whether cold- and warm-water species could be separated using this character in all genera at the same time. As can be seen from the last row of Table 2, the two subsamples do not pass the test for normality, and cold- and warm-water species can be only marginally separated using the Kolmogorov-Smirnov test $(\mathrm{p}$-value $=0.045)$.

\section{Discriminant analysis}

For this analysis the same a priori knowledge of palaeolatitude (as a proxy for water temperature) is used to classify each species into one of two mutually exclusive groups: cold-water 

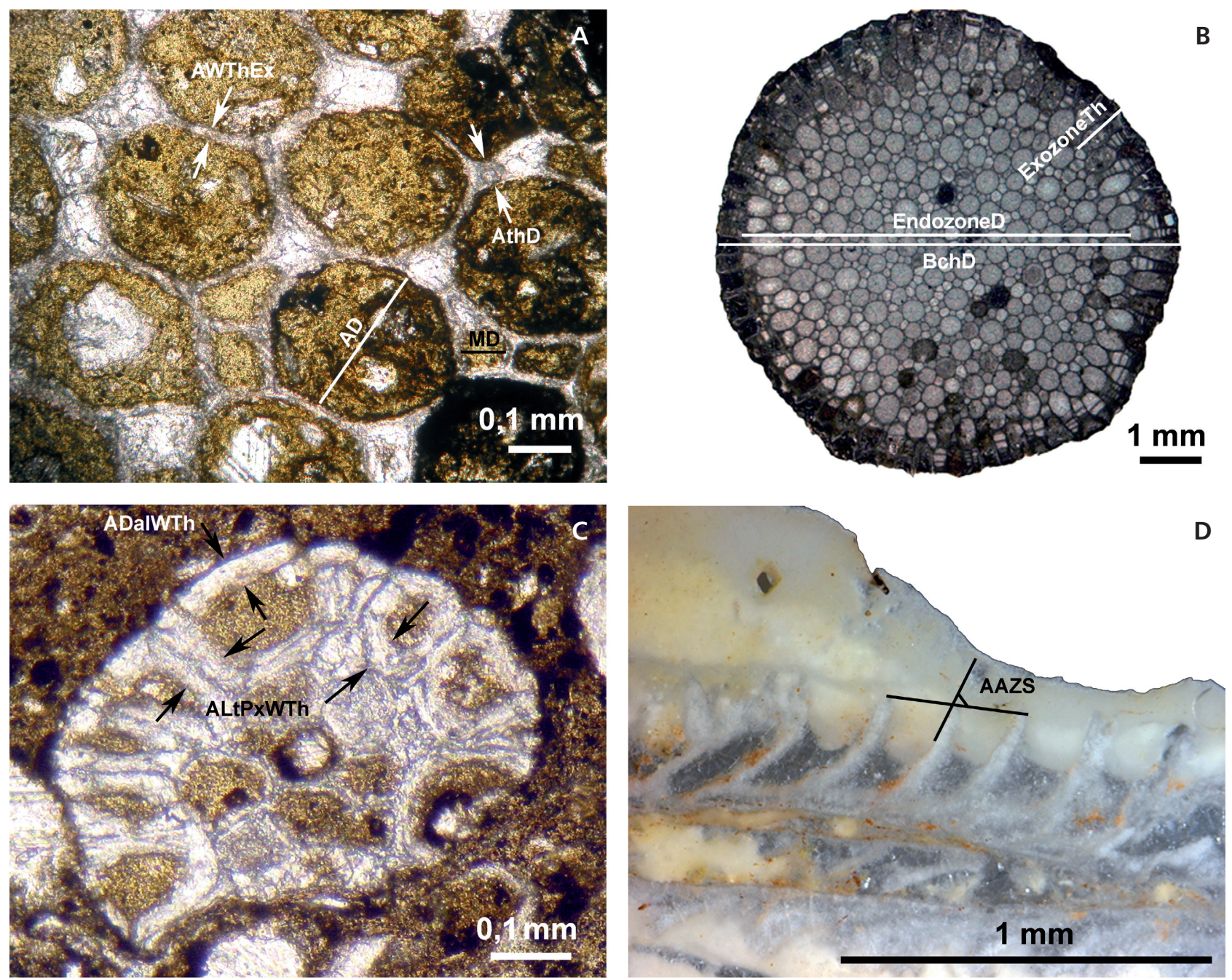

Figure 1. A - tangential section of Monticulipora cystiphragmata Jiménez-Sánchez, 2010 showing three types of measures: AD - autozooecial diameter; AthD - acanthostyle diameter; AWThEx - autozooecial wall thickness in exozone; and MD - mesozooecial diameter. The larger autozooecial diameter $\left(\mathrm{AD}_{\text {large }}\right)$ was measured in genera with oval autozooecial apertures. Zooecial wall thickness (ZWTh) was measured when the colony had a high number of mesozooecia. Exilazooecial diameter (ExiD) was measured in tangential sections of the genera Ceramopora and Ceramoporella. $\mathrm{N}^{\circ} \mathrm{A} 1 \mathrm{~mm}$, $\mathrm{N}^{\circ} \mathrm{A} 1 \mathrm{~mm}^{2}, \mathrm{~N}^{\circ} \mathrm{Ath} 1 \mathrm{~mm}^{2}, \mathrm{~N}^{\circ} \mathrm{M} 1 \mathrm{~mm}$ and $\mathrm{N}^{\circ} \mathrm{M} 1 \mathrm{~mm}^{2}$ have been also measured in tangential sections. $\bullet \mathrm{B}-$ transverse section of Hallopora peculiaris (described by Buttler 1991) showing characters branch diameter (BchD), endozone diameter (EndozoneD) and exozone thickness (ExozoneTh). In the genus Graptiodictya, which has an ellipsoidal cross section, the endozone thickness (EndozoneTh) and the branch small diameter $\left(\mathrm{BchD}_{\text {small }}\right)$ were measured instead of endozone and branch diameter. $\bullet \mathrm{C}$ - transverse section of Kukersella borealis (described by Jiménez-Sánchez 2009) showing the three types of walls measured in Kukersella. $・$ D - longitudinal section of Ceramopora invenustra Bassler, 1911 showing how the autozooecial angle with the zoarial surface (AAZS) was measured. Number of mesozooecial diaphragms per one millimetre $\left(\mathrm{N}^{\circ} \mathrm{MDph} 1 \mathrm{~mm}\right)$ was also measured in this type of section.

species and warm-water species. A discriminant analysis was carried out for each of the 10 genera in the dataset.

The discriminant function for the genera Heterotrypa and Kukersella (Fig. 3) correctly classified all of the species (100\% success rate). For the genera Ceramoporella and Diplotrypa the success rate was only slightly below $95 \%$, although both genera gave a success rate of $100 \%$ when one species was excluded from the analysis ( $C$. inclinata Jiménez-Sánchez, 2009, from the Mediterranean Province, and D. moniliformis Bassler, 1911, from the Baltic Province; see Fig. 4). The remaining genera have discriminant functions with success rates between $67 \%$ and $90 \%$ (Fig. 5).

\section{Multivariate ordination analysis}

The multivariate ordination analyses, whose aim is to discover if samples belonging to different provinces can be ordered according to a temperature (palaeolatitude) gradient, gave variable results. Using Principal Components, Principal Coordinates, Correspondence and Detrended Correspondence analyses, species belonging to the genera Ceramopora, Eridotrypa, Hallopora, Heterotrypa, Kukersella and Monticulipora did not follow patterns consistent with the province they belonged to: the convex hulls for the species from each province overlap each other and thus there is 
Table 2. Results of the univariate statistical analysis.

\begin{tabular}{|c|c|c|c|c|c|c|c|c|c|c|}
\hline \multirow[t]{2}{*}{ Genus } & \multicolumn{2}{|c|}{ No. of samples } & \multicolumn{2}{|c|}{ Normality test } & \multirow{2}{*}{ F test } & \multirow{2}{*}{$\mathrm{t}$ test } & \multirow{2}{*}{ K-S test } & \multirow{2}{*}{$\mathrm{M}-\mathrm{W}$ test } & \multicolumn{2}{|c|}{ Mean } \\
\hline & Cold & Warm & Cold & Warm & & & & & Cold & Warm \\
\hline Ceramopora (AD) & 4 & 5 & 0.07759 & 0.9907 & 0.05718 & 0.56718 & 0.4772 & 1 & 0.425 & 0.376 \\
\hline Ceramopora (AWThEx) & 4 & 5 & 0.1612 & 0.03865 & $\theta .25194$ & $\theta .26861$ & 0.4772 & 0.3175 & 0.07 & 0.06 \\
\hline Ceramopora $($ ExiD) & 4 & 5 & 0.5774 & 0.4211 & 0.35677 & 0.31117 & 0.7543 & 0.373 & 0.14 & 0.116 \\
\hline Ceramoporella (AD) & 4 & 11 & 0.9033 & 0.492 & $3.6434 \mathrm{E}-06$ & 0.0003591 & 0.005224 & 0.001465 & 0.5125 & 0.21091 \\
\hline Ceramoporella (AWThEx) & 4 & 11 & 0.272 & 0.005451 & $\theta .020658$ & 0.81268 & 0.3294 & 0.9201 & 0.0325 & 0.034 \\
\hline Ceramoporella (ExiD) & 4 & 11 & 0.2353 & 0.04557 & $\theta .18313$ & $\theta .0002392$ & 0.005224 & 0.001465 & 0.19 & 0.09 \\
\hline Diplotrypa (AD) & 4 & 13 & 0.9109 & 0.1276 & 0.062265 & 0.0078819 & 0.009553 & 0.01975 & 0.5425 & 0.40385 \\
\hline Diplotrypa (MD) & 4 & 13 & 0.1612 & 0.06886 & 0.39698 & 0.0003457 & 0.003459 & 0.001681 & 0.18 & 0.12 \\
\hline Diplotrypa $\left(\mathrm{N}^{\circ} \mathrm{A} 1 \mathrm{~mm}\right)$ & 4 & 13 & 0.5706 & 0.3415 & 0.27607 & 0.2519 & 0.4044 & 0.2811 & 1.6125 & 1.9638 \\
\hline Diplotrypa (ZWTh) & 4 & 13 & 0.6283 & 0.00596 & $\theta .12871$ & 0.49542 & 0.8819 & 0.6092 & 0.0225 & 0.01869 \\
\hline Eridotrypa $(\mathrm{AD})$ & 5 & 17 & 0.05023 & 0.0002997 & 0.70558 & 0.25228 & 0.1073 & 0.08107 & 0.16 & 0.21 \\
\hline Eridotrypa (AWThEx) & 5 & 17 & 0.9683 & 0.006238 & $\theta .85275$ & 0.2559 & 0.5753 & 0.3284 & 0.0662 & 0.087 \\
\hline Eridotrypa $(\mathrm{BchD})$ & 5 & 17 & 0.6611 & 0.01403 & $\theta .23458$ & $\theta .02719$ & 0.01296 & 0.00824 & 1.938 & 4.194 \\
\hline Graptodictya $\left(\mathrm{AD}_{\text {large }}\right)$ & 5 & 4 & 0.04354 & 0.4064 & $\theta .11042$ & $\theta .4841$ & 0.3572 & 0.5159 & 0.114 & 0.1275 \\
\hline Graptodictya $\left(\mathrm{BchD}_{\text {small }}\right)$ & 5 & 4 & 0.001942 & 0.3478 & $\theta .3883$ & 0.78045 & 0.8778 & 0.9048 & 0.8 & 0.7125 \\
\hline Graptodictya (EndozoneTh) & 5 & 4 & 0.7399 & 0.006192 & $\theta .0006888$ & 0.75131 & 0.08215 & 0.254 & 0.194 & 0.23 \\
\hline Hallopora (AAZS) & 9 & 23 & 0.04143 & 0.001587 & $\theta .055239$ & $\theta .30267$ & 0.8257 & 0.5973 & 76.463 & 81.269 \\
\hline Hallopora (AD) & 9 & 23 & 0.5126 & 0.2652 & 0.24297 & 0.007662 & 0.01339 & 0.01329 & 0.35556 & 0.2556 \\
\hline Hallopora (AWThEx) & 9 & 23 & 0.1864 & 0.179 & 0.031724 & 0.086003 & 0.0296 & 0.1648 & 0.05989 & 0.04217 \\
\hline Hallopora $(\mathrm{BchD})$ & 9 & 23 & 0.9721 & 0.8158 & 0.28221 & 0.93246 & 0.9849 & 0.8998 & 5.6756 & 5.7557 \\
\hline Hallopora (MD) & 9 & 23 & 0.9041 & 0.05718 & 0.47178 & 0.0018407 & 0.01339 & 0.002971 & 0.13778 & 0.0813 \\
\hline Hallopora $\left(\mathrm{N}^{\circ} \mathrm{A} 1 \mathrm{~mm}^{2}\right)$ & 9 & 23 & 0.02763 & $3.529 \mathrm{E}-05$ & $2.8904 \mathrm{E}-05$ & 0.025826 & $5.665 \mathrm{E}-05$ & 0.0003645 & 4.4311 & 12.17 \\
\hline Hallopora $\left(\mathrm{N}^{\circ} \mathrm{MDph} 1 \mathrm{~mm}\right)$ & 9 & 23 & 0.1983 & 0.001328 & $\theta .61405$ & $\theta .35048$ & 0.02743 & 0.2144 & 14.909 & 16.849 \\
\hline Heterotrypa (AAZS) & 2 & 3 & 1 & 0.6369 & 0.18996 & 0.63328 & 0.7796 & 1 & 83.5 & 80.667 \\
\hline Heterotrypa (AD) & 2 & 3 & 1 & 0 & 0.69069 & 0.78878 & 0.7796 & 0.7 & 0.255 & 0.25 \\
\hline Heterotrypa (AthD) & 2 & 3 & 1 & 0.6369 & 0.21773 & 0.24009 & 0.4249 & 0.4 & 0.08 & 0.0433 \\
\hline Heterotrypa (AWThEx) & 2 & 3 & 1 & 1 & 0.14305 & 0.11073 & 0.06267 & 0.2 & 0.075 & 0.03 \\
\hline Heterotrypa $(\mathrm{BchD})$ & 2 & 3 & 1 & 0.6369 & 0.13524 & 0.45034 & 0.7796 & 0.8 & 4.94 & 6.3333 \\
\hline Heterotrypa (EndozoneD) & 2 & 3 & 1 & 1 & 0.069273 & 0.15405 & 0.06267 & 0.2 & 2.395 & 3.75 \\
\hline Heterotrypa (ExozoneTh) & 2 & 3 & 1 & 1 & 0.0005946 & 0.55962 & 0.7796 & 1 & 1.52 & 1.12 \\
\hline Heterotrypa (MD) & 2 & 3 & 1 & 0.2983 & 0.031105 & 0.41095 & 0.4249 & 0.5 & 0.1005 & 0.1233 \\
\hline Heterotrypa $\left(\mathrm{N}^{\circ} \mathrm{A} 1 \mathrm{~mm}^{2}\right)$ & 2 & 3 & 1 & 1 & 0.14019 & 0.19187 & 0.06267 & 0.2 & 9.15 & 20.75 \\
\hline Heterotrypa $\left(\mathrm{N}^{\circ} \mathrm{A} 1 \mathrm{~mm}\right)$ & 2 & 3 & 1 & 0.9921 & 0.57848 & 0.072393 & 0.06267 & 0.2 & 2.41 & 3.8833 \\
\hline
\end{tabular}

no way to separate the provinces. The genus Hallopora shows the highest degree of overlap (Fig. 6), an unexpected result since Hallopora is one of the genera whose subsamples are most easily separable using the univariate analysis (see Table 2). In order to see if the results for Hallopora could be improved, we repeated the multivariate analysis using only those characters that gave positive results in the univariate analysis (five of the seven characters: Table 2). The results did not change and the convex hulls of the provinces were still superimposed.

On the other hand, the multivariate analyses gave better results for Ceramoporella, Diplotrypa, Graptodictya and Trematopora. Species of the genus Ceramoporella (Fig. 7) are clearly clustered by palaeogeographical province, and the convex hull of each province does not overlap with other hulls in any of the multivariate techniques used. The species $C$. grandis (Ernst \& Key, 2007) from the Mediterranean Province and $C$. interporosa (Ulrich, 1893) from the Laurentian-Siberian Province are the most distant from the centres of their respective provinces. Species of the genus Diplotrypa (Fig. 8) are also clustered by province, but in this case with a slight overlap between the Baltic and Laurentian-Siberian provinces (D. moniliformis, defined by Bassler, 1911 from the Baltic Province, plots inside the convex hull of the Laurentian-Siberian species); also Diplotrypa cf. westoni (Maw et al., 1976) from Burma (whose inclusion in the Mediterranean Province is uncertain) plots very close to the Baltic Province polygon. The positions of different species of Diplotrypa seem to have no correlation with temperature gradients. 
Table 2. continued

\begin{tabular}{|c|c|c|c|c|c|c|c|c|c|c|}
\hline \multirow[t]{2}{*}{ Genus } & \multicolumn{2}{|c|}{ No. of samples } & \multicolumn{2}{|c|}{ Normality test } & \multirow{2}{*}{ F test } & \multirow{2}{*}{ t test } & \multirow{2}{*}{ K-S test } & \multirow{2}{*}{ M-W test } & \multicolumn{2}{|c|}{ Mean } \\
\hline & Cold & Warm & Cold & Warm & & & & & Cold & Warm \\
\hline Kukersella (AD) & 2 & 10 & 1 & 0.03247 & 0.97811 & $\theta .84363$ & 0.3959 & 0.6667 & 0.13 & 0.136 \\
\hline Kukersella (ADalWTh) & 2 & 10 & 1 & 0.05002 & 0.23652 & 0.0092321 & 0.05321 & 0.09091 & 0.021 & 0.0411 \\
\hline Kukersella (AltPxWTh) & 2 & 10 & 1 & 0.08975 & 0.48578 & 0.013811 & 0.05321 & 0.0303 & 0.0105 & 0.036 \\
\hline Kukersella $(\mathrm{BchD})$ & 2 & 10 & 1 & 0.8052 & 0.22428 & 0.13932 & 0.1139 & 0.2727 & 0.545 & 0.833 \\
\hline Kukersella (EndozoneD) & 2 & 10 & 1 & 0.4946 & 0.0071644 & 0.16992 & 0.1139 & 0.2576 & 0.2005 & 0.367 \\
\hline Kukersella (ExozoneTh) & 2 & 10 & 1 & 0.0276 & $\theta .019733$ & $\theta .3122$ & 0.2227 & 0.4091 & 0.1605 & 0.204 \\
\hline Monticulipora (AD) & 2 & 19 & 1 & 0.001698 & $\theta .21754$ & $\theta .0017515$ & 0.02726 & 0.009524 & 0.355 & 0.2207 \\
\hline Monticulipora (MD) & 2 & 19 & 1 & 0.1032 & 0.81122 & 0.032632 & 0.06714 & 0.06667 & 0.125 & 0.0826 \\
\hline Monticulipora $\left(\mathrm{N}^{\circ} \mathrm{A} 1 \mathrm{~mm}^{2}\right)$ & 2 & 19 & 1 & 0.9662 & 0.226 & 0.090286 & 0.04335 & 0.05714 & 8.35 & 19.126 \\
\hline Monticulipora $\left(\mathrm{N}^{\circ} \mathrm{A} 1 \mathrm{~mm}\right)$ & 2 & 19 & 1 & 0.0003672 & $\theta .264$ & $\theta .045328$ & 0.01669 & 0.009524 & 2.75 & 4.702 \\
\hline Monticulipora $\left(\mathrm{N}^{\circ} \mathrm{M} 1 \mathrm{~mm}^{2}\right)$ & 2 & 19 & 1 & 0.0004178 & $\theta .37746$ & $\theta .41612$ & 0.7899 & 0.5143 & 4.6 & 13.039 \\
\hline Monticulipora $\left(\mathrm{N}^{\circ} \mathrm{M} 1 \mathrm{~mm}\right)$ & 2 & 19 & 1 & 3.399E-05 & $\theta .12149$ & 0.78268 & 0.3988 & 0.6762 & 1.05 & 1.235 \\
\hline Monticulipora (ZWTh) & 2 & 19 & 1 & 0.01334 & 0.95755 & 0.41605 & 0.2954 & 0.5905 & 0.015 & 0.0215 \\
\hline Trematopora (AD) & 8 & 4 & 0.005044 & 0.4043 & $\theta .65231$ & $\theta .032954$ & 0.1502 & 0.04848 & 0.11125 & 0.1725 \\
\hline Trematopora (AthD) & 8 & 4 & 0.6257 & 0.4877 & 0.49354 & 0.057387 & 0.3788 & 0.1212 & 0.05125 & 0.025 \\
\hline Trematopora (AWThEx) & 8 & 4 & 0.004482 & 0.6806 & $\theta .0054533$ & $\theta .15$ & 0.04809 & 0.02222 & 0.116 & 0.02225 \\
\hline Trematopora $(\mathrm{BchD})$ & 8 & 4 & 0.6373 & 0.7679 & 0.27576 & 0.79224 & 0.7399 & 0.6828 & 2.3075 & 2.4675 \\
\hline Trematopora (MD) & 8 & 4 & 0.425 & 0.85 & 0.91122 & 0.42582 & 0.9857 & 0.5333 & 0.06875 & 0.0775 \\
\hline Trematopora $\left(\mathrm{N}^{\circ} \mathrm{A} 1 \mathrm{~mm}^{2}\right)$ & 8 & 4 & 0.0319 & 0.3207 & $\theta .031865$ & $\theta .68906$ & 0.3788 & 0.3394 & 12.582 & 11.54 \\
\hline Trematopora $\left(\mathrm{N}^{\circ} \mathrm{A} 1 \mathrm{~mm}\right)$ & 8 & 4 & 0.3947 & 0.8862 & 0.13548 & 0.36096 & 0.3788 & 0.6828 & 3.8687 & 2.675 \\
\hline Trematopora $\left(\mathrm{N}^{\circ}\right.$ Ath $\left.1 \mathrm{~mm}^{2}\right)$ & 8 & 4 & 0.00955 & 0.008004 & 0.46253 & 0.45525 & 0.04809 & 0.1414 & 32.683 & 19.375 \\
\hline All genera (AD) & 45 & 109 & 0.0007871 & $1.835 \mathrm{E}-05$ & $4.3255 \mathrm{E}-06$ & 0.062164 & 0.0449 & 0.6518 & 0.28578 & 0.24233 \\
\hline
\end{tabular}

The nine species of the genus Graptodictya (Fig. 9) cluster around two clearly differentiated points: one group includes Laurentian-Siberian species and the other the Mediterranean Province, although in this group the species $G$. vinassae, described by Conti (1990) from Sardinia, plots a large distance from the other Mediterranean Province species. The only Graptodictya species from the Baltic Province plots far from both the Mediterranean and Laurentia-Siberia provinces, precluding this genus from defining a clear temperature gradient.

Lastly, species of the genus Trematopora (Fig. 10) form two clusters, the larger of which is composed by the species from the Mediterranean Province, with T. acanthostylita Jiménez-Sánchez, 2009 being the species most distant from the centre of the cluster. The smaller cluster groups species from the Baltic Province. In two of the multivariate analyses (Correspondence and Detrended Correspondence), Trematopora? promigenia (Ulrich, 1893) from the Laurentian-Siberian Province plots inside the convex hull of the Mediterranean Province. As in previous analyses, no clear temperature gradient is apparent.

\section{Conclusions}

Ten different eurythermic bryozoan genera from the Upper Ordovician have been studied in order to test whether mor- phological differences exist between cold- and warmwater species. The study was carried out on 154 samples belonging to 104 different species. Twenty-eight morphological characters were measured, although only 21 were used in the final statistical analysis. For the univariate and discriminant analysis, the total sample of species was divided into cold- and warm-water subsamples: species from Mediterranean Province were attributed to the cold-water subsample, whereas species from Avalonia, Baltic and Laurentian-Siberian provinces were included in the warm-water subsample. No a priori grouping by water temperature was imposed in the multivariate ordination analysis performed subsequently, where the aim was to test whether different species, colour coded by palaeogeographical province, were correctly arranged along a water temperature gradient.

Statistical analyses allowed the following conclusions to be drawn:

1. The univariate statistical analysis showed that there are clear morphological differences between cold-and warm-water species (i.e., from high and low latitudes, respectively) in more than half of the Upper Ordovician bryozoan genera analysed in this study (Ceramoporella, Diplotrypa, Eridotrypa, Hallopora, Monticulipora and Trematopora), although these differences are only evident for some of the 21 characters used, and only when the analysis is 


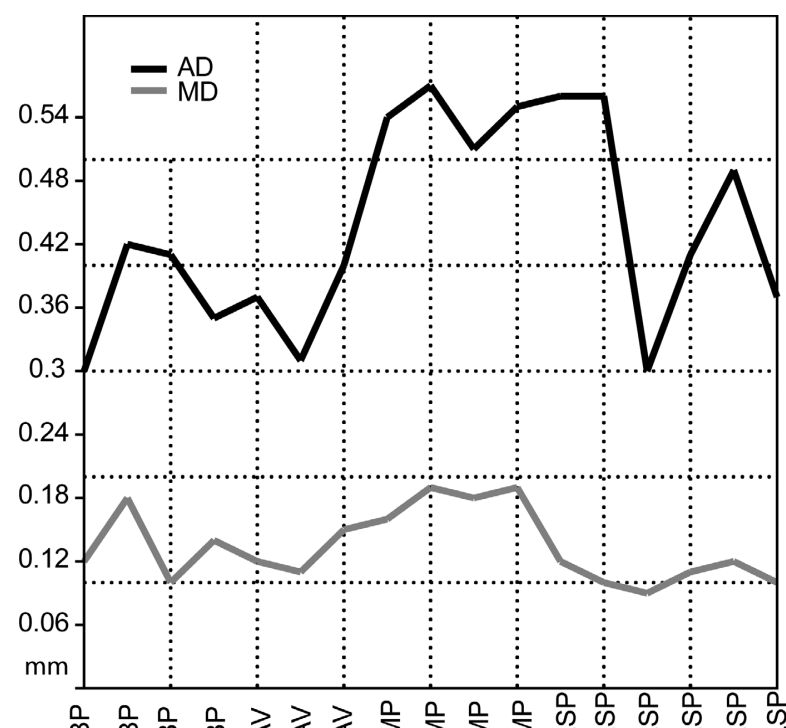

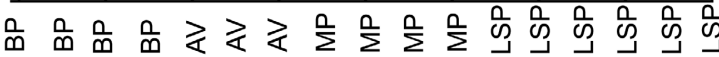
AV - Avalonia region BP - Baltic province
LSP - Laurentia-Siberia province MP - Mediterranean province

Figure 2. Relationship between autozooecial diameter (AD) and mesozooecial diameter (MD) in the genus Diplotrypa. It can be observed that larger diameters, both in autozooecia and mesozooecia, belong to species coming from the Mediterranean Province (proxy for cold-water).

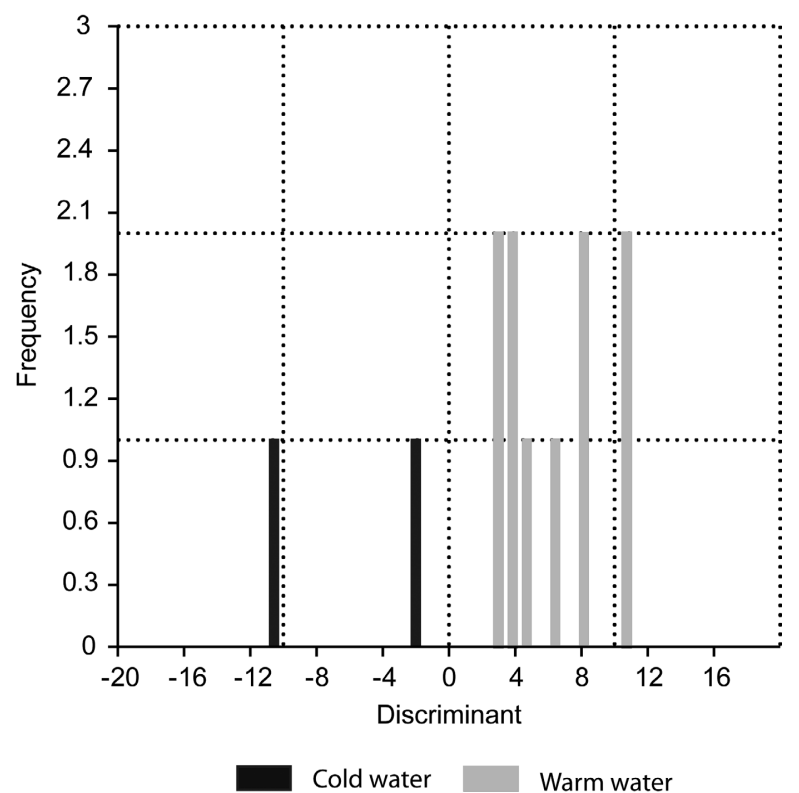

Figure 3. Discriminant analysis of the genus Kukersella with the subsets from cold- and warm-water clearly separated. The discriminant function separates correctly $100 \%$ of the samples. The discriminant function is: $-88.594 \times \mathrm{AD}+245.49 \times \mathrm{ALtPxWTh}+148.1 \times \mathrm{ADalWTh}-3.8485 \times$ EndozoneD $+64.107 \times$ ExozoneTh $+27.09 \times \mathrm{BchD}$

performed on individual genera. When all 10 genera were pooled together no statistically significant differences between warm- and cold-water species could be found.

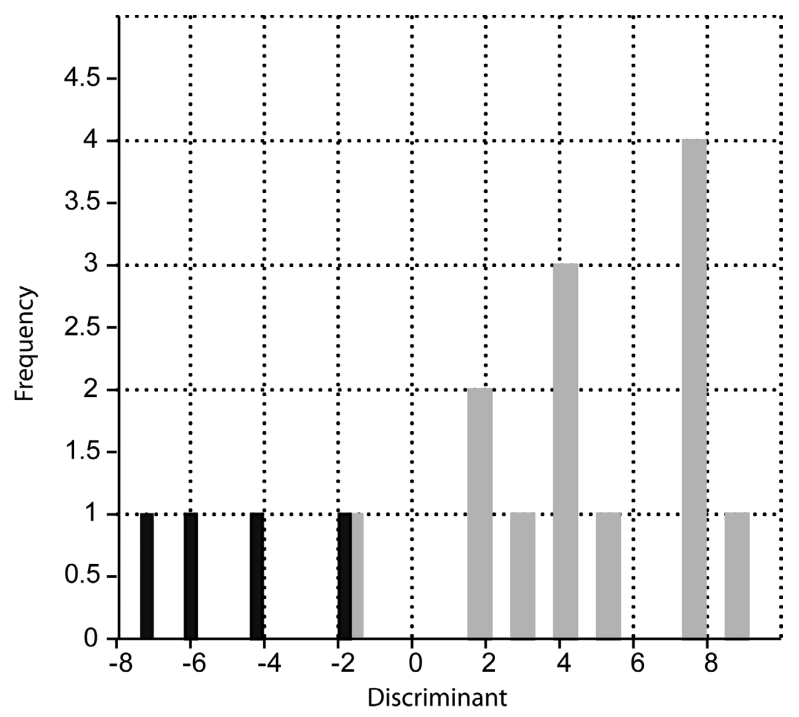

Figure 4. Discriminant analysis of the samples belonging to the genus Diplotrypa. In this case the percentage of samples correctly discriminated is slightly less than $95 \%$; one sample of D. moniliformis Bassler, 1911 was placed in the field of cold-water samples.

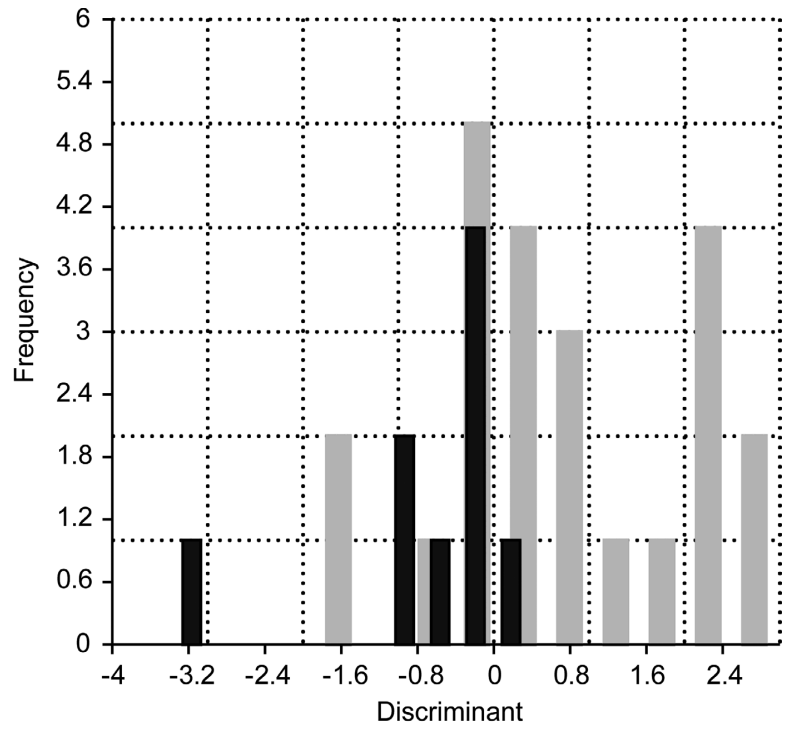

Figure 5. Discriminant analysis of the genus Hallopora showing a case of poor discrimination between cold- and warm-water subsets.

2. Genera from the order Trepostomata show the greatest temperature-related morphological differences.

3 . The best characters to differentiate species by water temperature are those related to the size of the zooidal polymorphs, especially the diameters of the autozooecia, mesozooecia and exilazooecia. With the exception of one genus (Trematopora), cold-water species have larger zooids. This finding is consistent with the inverse correlation between temperature and zooid size among Recent cheilostome bryozoans, although this relationship has been best established between zooids 


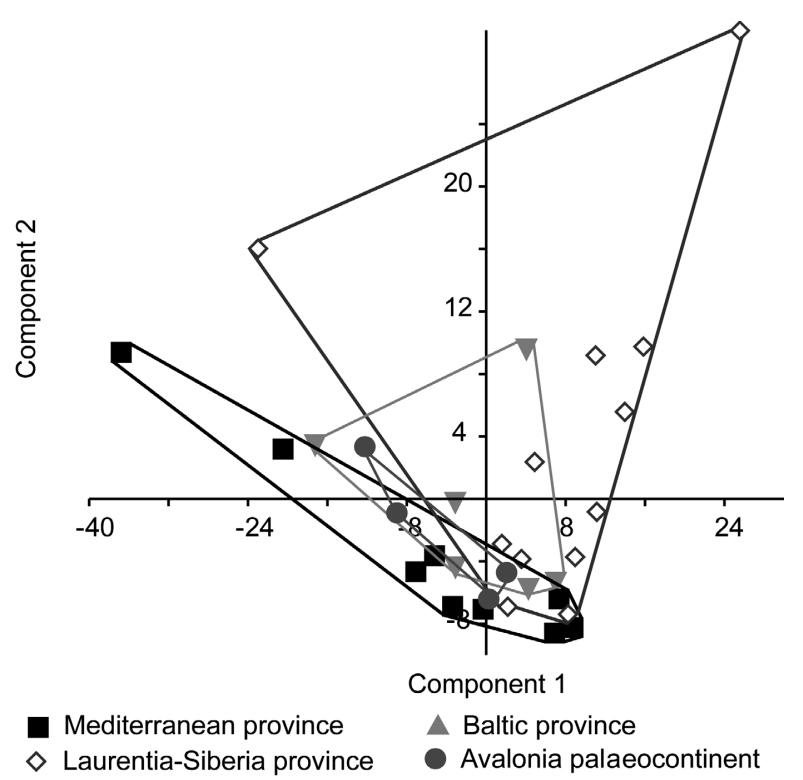

Figure 6. Principal Component analysis of the samples belonging to the genus Hallopora. The high degree of overlap between provinces does not allow differentiation of the bryozoan provinces present in the Upper Ordovician.

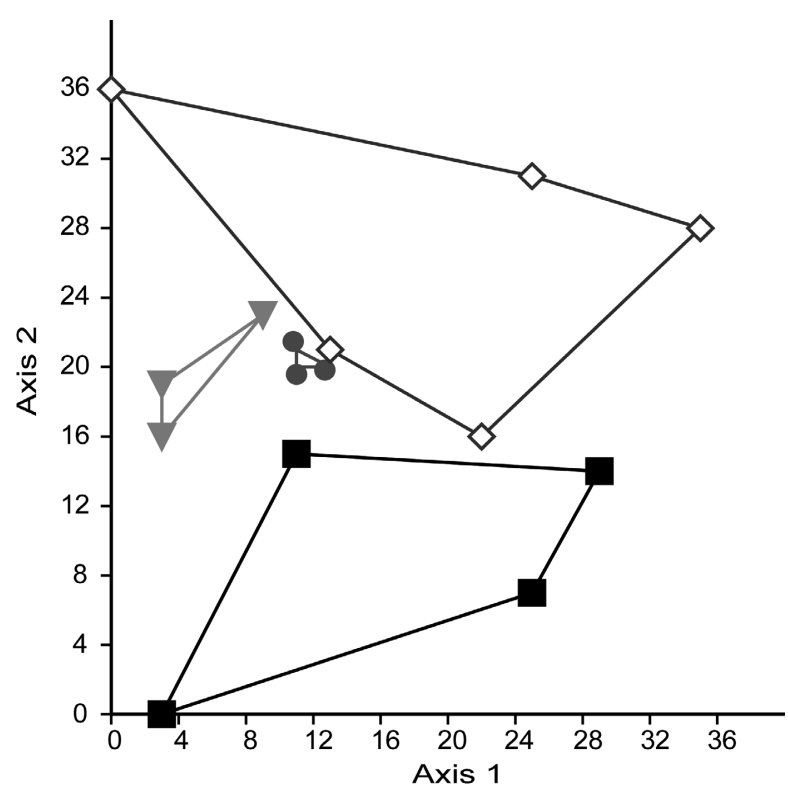

Figure 7. Detrended Correspondence analysis of the species belonging to the genus Ceramoporella. For this genus the different provinces are clearly differentiated, with no overlap between provinces.

within colonies and between colonies of the same species rather than between species within genera as here (Kuklinski \& Taylor 2008).

4. The discriminant analysis showed the success rate of the discriminant function to be $100 \%$ for two genera (Heterotrypa and Kukersella), slightly below 95\% for two other genera, and between $67 \%$ and $90 \%$ for the remaining

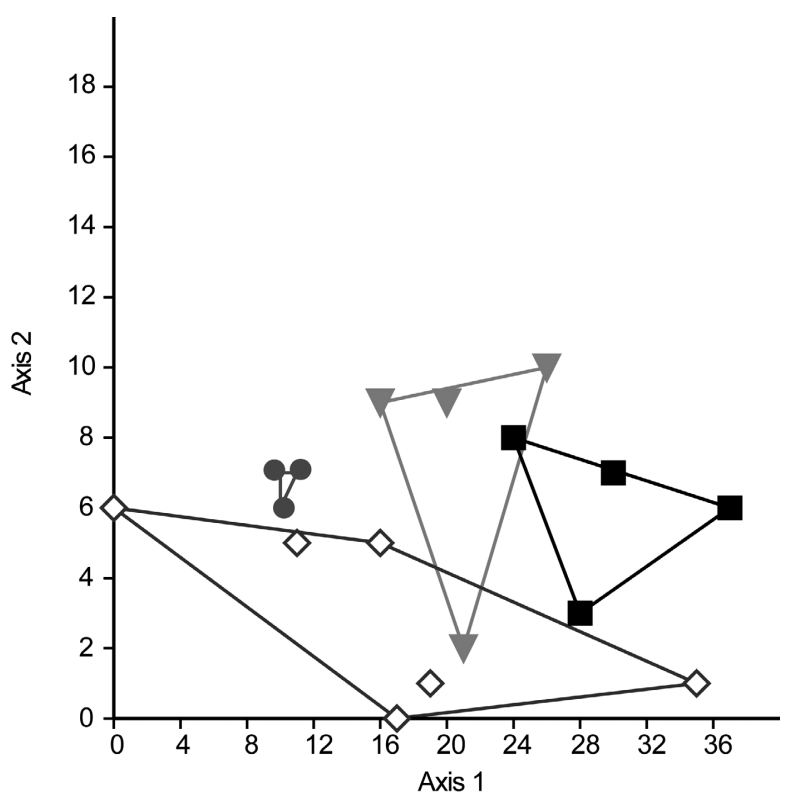

Figure 8. Detrended Correspondence analysis for species of the genus Diplotrypa. The samples belonging to this genus are well separated according to province, but there is a slight overlap between three provinces.

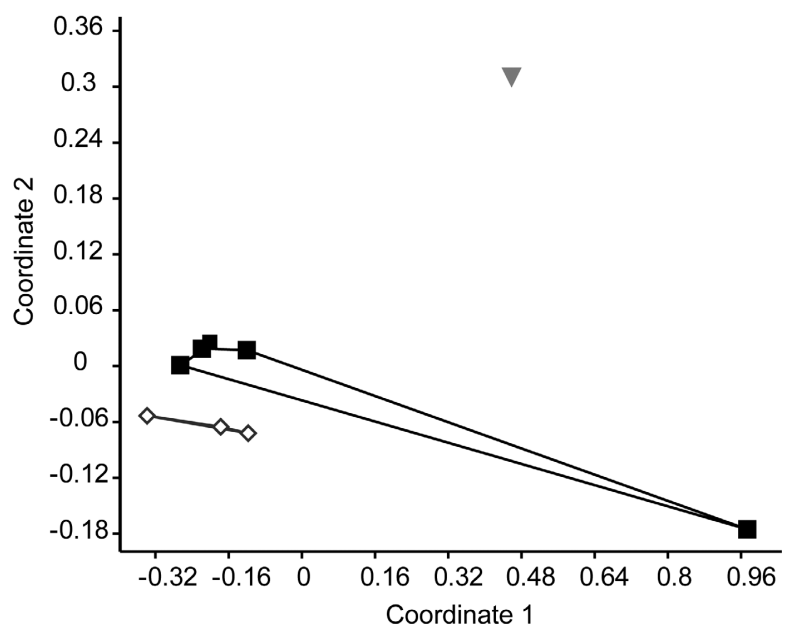

Figure 9. Principal Coordinate analysis of the genus Craptodiptya. The few samples analysed of this genus are correctly arranged by provinces, but the sample belonging to $G$. vinassae plots far away from the rest of the Mediterranean samples and the only species of the Baltic Province plots a large distance from both the Mediterranean and Laurentia-Siberia provinces.

six genera. This means that a robust classification of a new species of a specific genus as warm- or cold-water is not possible in most cases.

5. The multivariate ordination analysis was able to separate species by palaeogeographical province in some genera, but these provinces were not arranged along a correct temperature gradient using any of the methods tested (Principal Coordinates, Principal Components, Correspondence, and Detrended Correspondence analyses). This lack of correlation between temperature gradient and bryozoans provinces may 


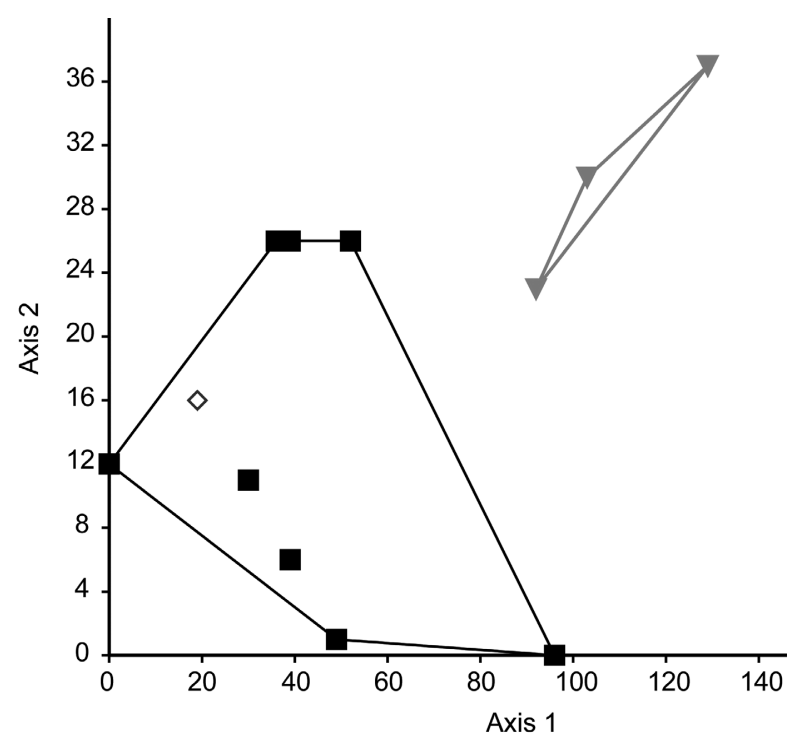

Figure 10. Detrended Correspondence analysis of the genus Trematopora. There is a good separation between the Baltic and the Mediterranean provinces. The only species belonging to the Laurentia-Siberian Province plots inside the convex hull of the Mediterranean Province.

be due to the increase in water temperature (Boda event) prior to the Hirnantian glaciation (Fortey \& Cocks 2005).

\section{Acknowledgements}

We would like to acknowledge the financial support of a Synthesys grant that funded a visit by A.J.-S. to the Natural History Museum, London TAF. For additional funding, we thank the Spanish Ministry of Science and Innovation project CGL 2009-09583 and the Aragón Government project E-17 "Patrimonio y Museo Paleontológico", with the participation of the European Social Fund. Constructive comments made by two referees (Caroline Buttler and Steve Hageman) were greatly appreciated. This paper is a contribution to the IGCP 591 project.

\section{Bibliography}

BASSLER, R.S. 1911. The early Paleozoic Bryozoa of the Baltic provinces. United States National Museum Bulletin 77, 1-382.

ButTLER, C.J. 1991. A new upper Ordovician bryozoan fauna from the Slade and Redhill Beds, South Wales. Palaeontology $34,77-108$.

Cocks, L.R.M. \& ToRsvik, T.H. 2006. European geography in a global context from the Vendianto the end of the Palaeozoic. Journal of the Geological Society of London 32, 83-95. DOI 10.1144/GSL.MEM.2006.032.01.05

ConTI, S. 1990. Upper Ordovician Bryozoa from Sardinia. Palaeontographia Italica $77,85-165$.

Ernst, A. \& Key, M. 2007. Upper Ordovician Bryozoa from the Montagne de Noire, Southern France. Journal of Systematic Palaeontology 5, 359-428. DOI 10.1017/S1477201907002155

ForTEY, R.A. \& CoCKS, L.R.M. 2003. Palaeontological evidence bearing on global Ordovician-Silurian continental reconstruc- tions. Earth-Science Reviews 61, 245-307.

DOI 10.1016/S0012-8252(02)00115-0

ForTeY, R.A. \& COCKS, L.R.M. 2005. Late Ordovician global warming - the Boda event. Geology 33, 405-408.

DOI $10.1130 / \mathrm{G} 21180.1$

Hammer, Ø., Harper, D.A.T. \& Ryan, P.D. 2008. PAST v 2.15. Paleontological Statistics Software: Package for Education and Data analysis.

HugHES, D.J. \& JACKSON, J.B.C. 1990. Do constant environments promote complexity of form?: The distribution of bryozoan polymorphism as a test of hypotheses. Evolution 44, 889-905. DOI $10.2307 / 2409553$

JimÉNEZ-SÁNCHEZ, A. 2009. The upper Katian (Ordovician) bryozoans from the Eastern Iberian Chains (NE Spain). Bulletin of Geosciences 84, 687-738. DOI 10.3140/bull.geosci.1156

JiMÉNEZ-SÁNCHEZ, A. 2010. New Monticuliporidae (Trepostomata) from the Cystoid Limestone Formation (Upper Ordovician) of the Iberian Chains (NE Spain). Geodiversitas 32(2), 177-199. DOI 10.5252/g2010n2a1

JimÉnEZ-SÁncheZ, A. \& Villas, E. 2010. The bryozoan dispersion into the Mediterranean margin of Gondwana during the pre-glacial Late Ordovician. Palaeogeography, Palaeoclimatology, Palaeoecology 294, 220-231. DOI 10.1016/j.palaeo.2009.11.027

KuKLinski, P. \& TAYLOR, P.D. 2008. Are bryozoans adapted for living in the Arctic? Virginia Museum of Natural History, Special Publication 15, 101-110.

Loxton, J., Kuklinski, P., Mair, J.M., Jones, M.S. \& Porter, J.S. 2012. Patterns of magnesium-calcite distribution in the skeleton of some polar bryozoan species, 169-185. In ERNST, A., SchÄFER, P. \& Scholz, J. (eds) Bryozoan Studies. Springer, Heidelberg.

Maw, U.B., SAN, U.B. Ross, J.R.P. \& Ciochon, R.L. 1976. The Ordovician bryozoan (Ectoproct) Diplotrypa from Central Burma. Geological Magazine 113, 515-518. DOI 10.1017/S001675680004125X

OKamuRA, B., O’DeA, A. \& Knowles, T. 2011. Bryozoan growth and environmental reconstruction by zooid size variation. $M a-$ rine Ecology Progress Series 430, 133-146. DOI 10.3354/meps08965

SCHÄFER, P. \& BADER, B. 2008. Geochemical composition and variability in the skeleton of the bryozoan Cellaria sinuosa (Hassall): biological versus environmental control. Virginia Museum of Natural History, Special Publication 15, 269-278.

SChlager, W. 2005. Carbonate sedimentology and sequence stratigraphy. 200 pp. SEPM, Tulsa. DOI 10.2110/csp.05.08

Smith, A.M., Key, M.M. JR. \& Gordon, D.P. 2006. Skeletal mineralogy of bryozoans: taxonomic and temporal patterns. Earth-Science Reviews 78, 287-306.

DOI 10.1016/j.earscirev.2006.06.001

TAYLOR, P.D. \& Allison, P.A. 1998. Bryozoan carbonates through time and space. Geology 26, 459-462. DOI 10.1130/0091-7613(1998)026<0459:BCTTAS >2.3.CO;2

TAYlor, P.D., James, N.P., Bone, Y., Kuklinski, P. \& Kyser, T.K. 2009. Evolving mineralogy of cheilostome bryozoans. Palaios 24, 440-452. DOI 10.2110/palo.2008.p08-124r

TAYlor, P.D. \& Sendino, C. 2010. Latitudinal distribution of bryozoan-rich sediments in the Ordovician. Bulletin of Geosciences 85, 565-572. DOI 10.3140/bull.geosci.1177

UlRICH, E.O. 1893. On Lower Silurian Bryozoa of Minnesota. Minnesota Geology and Natural History Survey, Final Report 3(1), 96-332. 